\title{
Plassmann, Alheydis, Origo gentis. Identitäts- und Legitimitätsstiftung in früh- und hochmittelalterlichen Herkunftserzählungen
}

Damien Kempf

\section{CpenEdition}

Édition électronique

URL : http://journals.openedition.org/ifha/1654

DOI : $10.4000 /$ ifha. 1654

ISSN : 2198-8943

Éditeur

IFRA - Institut franco-allemand (sciences historiques et sociales)

Référence électronique

Damien Kempf, «Plassmann, Alheydis, Origo gentis. Identitäts- und Legitimitätsstiftung in früh- und hochmittelalterlichen Herkunftserzählungen », Revue de I'IFHA [En ligne], Date de recension, mis en ligne le 01 janvier 2008, consulté le 22 septembre 2020. URL : http://journals.openedition.org/ifha/1654 ; DOI : https://doi.org/10.4000/ifha.1654

Ce document a été généré automatiquement le 22 septembre 2020.

(C)IFHA 


\title{
Plassmann, Alheydis, Origo gentis. Identitäts- und Legitimitätsstiftung in früh- und hochmittelalterlichen Herkunftserzählungen
}

\author{
Damien Kempf
}

Depuis quelques années, les récits consacrés à l'origine des peuples - origo gentis - sont à nouveau au centre des discussions historiques. Deux grandes écoles dominent le débat. D'un côté, le cercle de Vienne, qui s'est constitué autour d'Herwig Wolfram, s'intéresse à l'ethnogenèse des peuples germaniques, suivant la voie ouverte par les travaux de Reinhard Wenskus. De l'autre, Walter Goffart et ses collaborateurs ont remis en question la conception des origines gentium et prônent ainsi l'idée que chaque auteur avait sa motivation propre pour élaborer son œuvre. L'auteure de ce livre, qui est issu d'une habilitation à rédiger des recherches présentées à l'Université de Bonn, s'inscrit plutôt dans la lignée des idées développées par H. Wolfram. Deux questions sont au cœur de cet ouvrage : il s'agit de savoir d'abord comment une origo gentis peut créer une identité et, ensuite, comment l'écriture d'un texte peut légitimer un ordre existant. La démonstration s'ordonne autour de textes-clés composés entre le VIe et le XIIe s., parmi lesquels le De Excidio et conquestu Britanniae de Gildas, l'Historia ecclesiatica gentis Anglorum de Bède, l'Historia Brittonum, les Dix livres d'histoire de Grégoire de Tours, la Chronique de Frédégaire, le Liber historiae Francorum, l'Histoire des Lombards de Paul Diacre, l'Histoire des Normands de Dudon de Saint-Quentin, ou encore la Chronique du Gallus Anonymus, qui est le premier récit à décrire la naissance de l'État polonais. L'auteur observe très peu de changements entre le VIe et le XIIe s. dans la façon dont les identités étaient créées et les légitimités revendiquées, notamment en ce qui concerne l'utilisation ou l'invention des noms, l'image des " autres ", et le positionnement des siens dans le plan du Salut. Ce qui change, en revanche, ce sont les objets ou les unités territoriales : une gens, une région ou un empire. Grâce à son approche systématique et minutieuse, et une bibliographie détaillée, cet ouvrage constitue un précieux instrument de travail. 
Damien Kempf (Université de Bristol) 